\title{
Transforming serials: The revolution continues. \\ Proceedings of the North American Serials Interest Group, Inc. 17th Annual Conference, June 20-23, 2002, the College of William and Mary, Williamsburg, Virginia. Edited by Susan L Scheiberg and Shelley Neville.
}

London: Haworth Information Press, 2003. 365p.

ISBN 0789022826 (sb).

Price: US\$34.95

These proceedings have also been published in The Serials Librarian, Volume 44, Nos. I/2 and 3/4. The book comprises 43 chapters covering the preconference programmes, plenary sessions, concurrent sessions and workshops that took place at the conference. There is also a summary of the conference poster sessions, a list of the conference registrants, and the volume concludes with an index. A useful feature is the summary at the beginning of each chapter. As the annual conference of the North American Serials Interest Group, the presenters and recorders were mostly from North American academic institutions. The issues under discussion, though, are those faced by librarians internationally.

There are about 7 chapters that cover cataloguing issues relating to serials.

Jean Hirons and Leslie Hawkins (both from the Library of Congress, USA) jointly led a two-part workshop that dealt with the revised rules and amendments to chapters 9 and 12 of the AACR2, while Keiko Okuhara (Hillman Library, University of Pittsburgh, USA) provided guidelines and instruction on the cataloguing of microform reproductions and paper-based reprints using the revised AACR2.

A group of librarians from various institutions presented the pre-conference programme, Implementing MARC 21 for holdings. The advantage of implementing a standard format like this is that it facilitates the sharing of holdings information between institutions, much as libraries currently share bibliographic data.

The benefits of sharing also arose in Michael Kaplan and Kim Maxwell's presentation, ILS conversion and the prediction pattern conundrum: What do you do on day I? The presenters talked about the benefits of using shared prediction patterns as initiated by CONSER.

Paul Moeller and Wendy Baia also discussed sharing in Cataloging for consortium catalogs, where the purpose is to share consortium knowledge and experience.

There were a few sessions on electronic journals. Everything you always wanted to know about electronic journals but were afraid to ask was a workshop presented by Stefanie Wittenbach (Head of Acquisitions, University of California, Riverside Library, USA). It was designed to be an introduction for librarians new to electronic journals. The session covered three areas: acquisition/vendor issues; processing/online catalogue integration; public services/collection development.

Janet Palmer and Mark Sandler presented Get hip to e-journals and forget about the print: Inciting a faculty revolution? This presentation described a project undertaken at the University of Michigan, USA, to explore ways of relieving the pressures on storage space and the acquisitions budget. The study concentrated on the social sciences disciplines. Questions to which they sought answers were: which disciplines would be most accepting to electronic-access-only journals; what concerns are there regarding electronic-only-access; what do the responses suggest for future collection development? The general conclusion of the study was that faculty are ready to move to electronic-access-only, although there are still concerns about the loss of the print.

Stewart Brower and Janice M Krueger discussed ways to educate users about electronic journals, and how to use and cite them in Teaching electronic journals: Finding, using and citing them.

Electronic journal management systems were the topic of Management of electronic serials, outsourcing, and bringing new products to the marketplace. Peter McCracken (co-founder of Serials Solutions) and Mike Markwith (president of TDNet) each offered their insights into the field. McCracken covered the topic by selling the virtues of Serials Solutions, while Markwith offered a more objective view of the topic.

Gregory Szczyrbak and Louise Pierce discussed their evaluation of three electronic journal management systems at York University of Pennsylvania, USA. This comparison, done in 2001 covered Serials Solutions, Journal WebCite and TDNet. 
Another topic covered in a few sessions was the linking of electronic journals. Nettie Lagace (SFX Librarian with Ex Libris, USA) presented a session on The OpenURL and SFX linking. The OpenURL is an emerging standard that allows linking between resources. SFX is a link server that helps manage the maintenance and resolution of links. Other sessions dealt with how the online catalogue can be the tool to link users to full-text content.

Howard Strauss, in his paper Web portals: The future of information access and distribution, explains that a portal is more than simply a home page. Home pages are usually centred around an institution, whereas a portal should be focussed on the user. A portal allows quick access to the services and web pages the user uses regularly. The definition that Strauss provides for a portal is that it is "a user-centric customized, personalized, adaptive desktop (CPAD)."

Emily R Mobley presented Serials challenges and solutions: The view from the director's chair. The challenge Mobley focuses on is that of pricing issues of particularly scientific journals and what has caused the current pricing situation. The solutions she comes up with are initiatives like SPARC and the Budapest Open Access Initiative, which offer publication alternatives to the commercial publishers. Ultimately she feels there will be a move away from the current scholarly journal scenario to that of individual papers grouped together in some way online.

Rick Anderson and Steven D Zink presented How I learned to stop worrying and give up journal check-in. They discuss the experiences of the University of Nevada, Reno, USA, as they stopped the check-in of journal issues and binding, and started claiming from items on the shelf. Overall this revolution was counted a success.

Louis Houle and Chris Beckett explored Just in time vs. just in case: Examining the benefits of subsidized unmediated ordering (SUMO) vs. journal subscription. Houle showed that document delivery could be used as an alternative to journal subscription as well as to interlibrary loans. This conclusion is the result of a study done at McGill University, Canada, where the various costs associated with each method and the speed of delivery were compared. Beckett (Global Library Services, Ingenta) presented the results of a study done by the Ingenta Institute that came to the conclusion that, presently, document delivery is not a threat to journal subscriptions.

As a book, this volume would have more substance if the chapters were actual papers written by the presenters. Most of the contributions are reports of what took place in the particular workshop or presentation, written by a third party. Nonetheless, the variety of topics covered makes it worthwhile reading.

Reviewed by: Caroline E Dean, Electronic Resources Librarian, Collections Development Department, University of Cape Town Libraries, South Africa.

Tel.: $+27(21) 650370$ I

Email: caroline@uctlib.uct.ac.za 